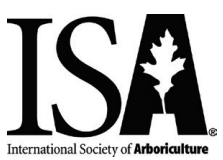

\title{
The Economic Value of Tree Preservation in a Weak Land Development Market Region
}

\author{
Wendy Kellogg, Brian Mikelbank, Robert Laverne, and Kathryn W. Hexter
}

\begin{abstract}
New residential development is most often a death sentence for the trees that stand in its way. This behavior might be altered if developers thought there was an economic value to being more selective. Unfortunately, the relationship between tree preservation and new development is not well studied. The purpose of this study was to characterize the economic value gained from the preservation of mature trees during the land development process. The study focused on six counties constituting the greater Cleveland, Ohio, U.S., real estate and land development market. A mixed quantitative and qualitative approach was used. GIS-based data and a series of hedonic models determined the value of tree canopy associated with new home sale prices from 2009 to 2011 . Qualitative interviews of development and real estate professionals revealed a nuanced association of value and challenges to tree preservation during the residential land development process. Previous methods for estimating the economic value of trees were moved forward through aerial location of trees on parcels using Google Earth ${ }^{\mathrm{Tw}}$ and the National Agricultural Imagery Program (NAIP) data and through the mixedmethod approach. The study provided information to a state-level agency managing the state's incentive-based smart growth program.

Key Words. Cleveland; Economic Value; Ohio; Real Estate; Satellite Imagery; Tree and Canopy Preservation.
\end{abstract}

Recent research, described herein, has explored the value of various open space, greenspace, vegetative materials, biodiversity, and ecosystem services. One important attribute in areas experiencing land urbanization is the preservation of existing mature trees and established tree canopy, and how such practices, beyond their environmental and social value, may influence the value of land as it is subdivided and sold. This question was the focus of a case study of six counties in northeastern Ohio, U.S. In the current case study, researchers sought to understand whether the preservation of trees had influenced land value as compared to land without such trees over a multi-year period, and to understand the perspective of land developers and home buyers for preservation of mature trees and existing tree canopy, as these would affect their decision-making. Researchers also sought to improve on previous methods for estimating the economic value of trees (photography from public rights-of-way) by using a combination of quantitative spatial data, exploring the use of Internet and satellite- derived data, and using qualitative data, which consisted of interviews with real estate agents and developers regarding home buyer preferences.

\section{CASE STUDY CONTEXT}

The study area regarded the greater Cleveland region in northeastern Ohio, U.S., an area of stable population shifting from the core county in low-density development patterns into previously forested, field, or working landscapes in the five surrounding counties (Figure 1). The six counties in the study area are differentiated by their history and relative level of urbanization. Cuyahoga County, the center of the study area, contains the City of Cleveland, founded in 1796, and its suburbs, built out in the 1920s through the 1990s. The county is virtually all urbanized/suburbanized today (Bier 2001). Summit County, which contains Akron, Ohio, is predominantly urban and suburban as well. In the last two decades, the counties surrounding Cuyahoga County have experienced increased land development, as people and businesses moved out of Cuyahoga. More 
people now live in the counties surrounding Cuyahoga County than in the core county. $\mathrm{Nu}-$ merous historic small villages that have grown into small cities in this period dot the landscapes of these outlying counties, which, beyond the areas adjacent to Cuyahoga County, remain predominantly rural, either in large lot residential properties, in forest, or as agricultural landscapes.

Northeastern Ohio exemplifies the relatively weak policy and planning culture and home-rule dominance found in Great Lakes states, which elevates the importance of market forces and government incentives, rather than legislation, to influence land development location and practices. Output from the study informs state-level programs to address the fiscal and environmental consequences of lowdensity exurban development patterns (Pendall 2003; Boyle and Mohamed 2007; Kellogg 2007).

\section{LITERATURE REVIEW AND CON- CEPTUAL FRAMEWORK}

\section{Measuring the Economic Benefits of Trees}

Forestry and water resource managers suggest that trees provide a wide range of benefits to communities (Dwyer et al. 1992; Hudson 2000), which accrue in environmental improvements (e.g., air quality, urban heat island effect reduction, water quality improvements) (Nowak 1994; Akbari et al. 2001; Nowak and Crane 2002; Xiao and McPherson 2002; Jeng et al. 2005; McPherson et al. 2006; Nowak et al. 2007; Rossi and Hari 2007; Young 2011), social conditions (e.g., noise abatement, enhanced social interaction) (Dwyer et al.1992), and economic value (e.g., energy conservation) (Laverne and Lewis 1996) in urban life. These benefits are, of course, interdependent, and the social and environ-

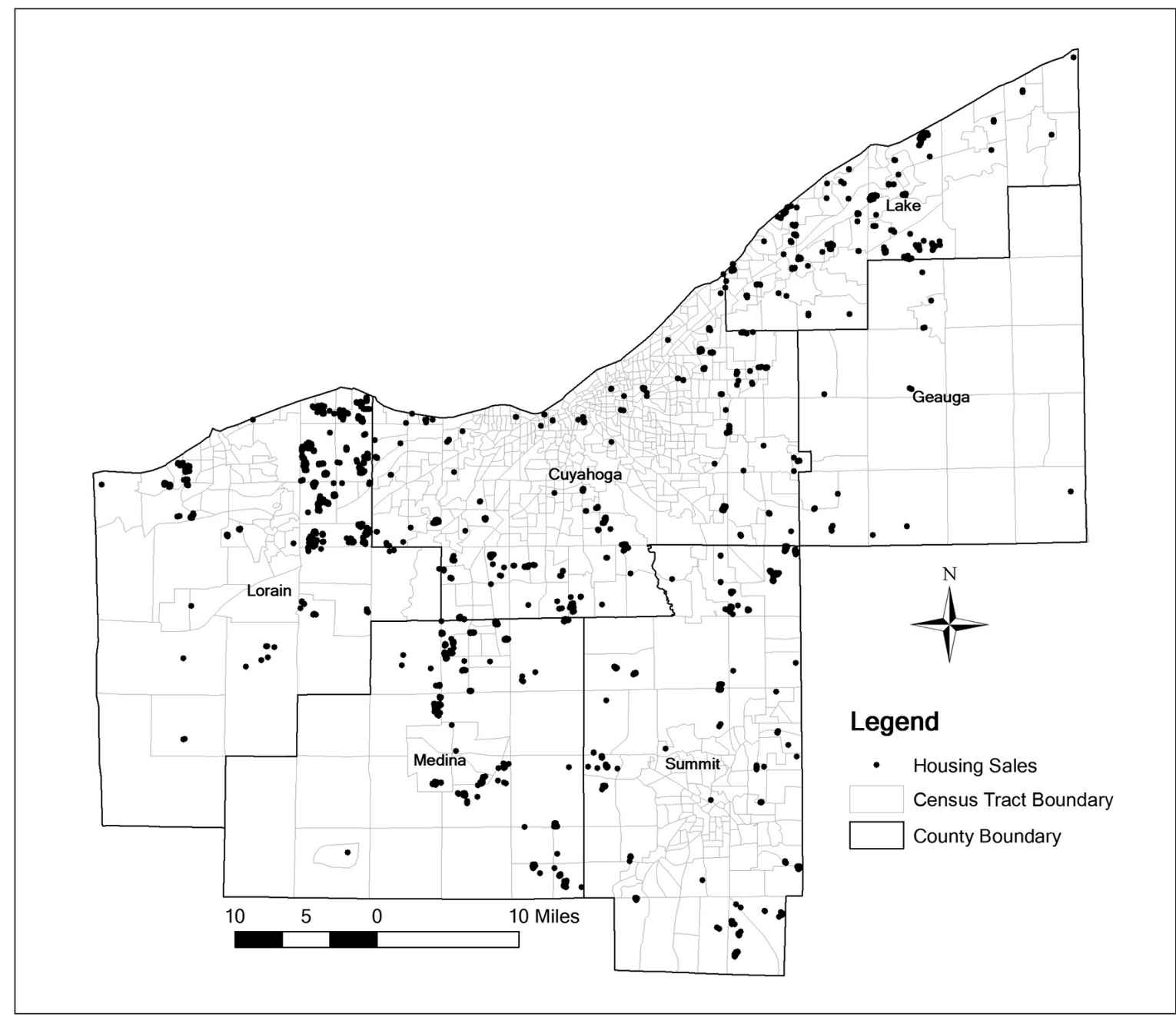

Figure 1. Housing Sale Location in Six County Study Area, 2009-2011. 
mental benefits, if appreciated by potential home buyers, may also affect the economic value of trees as expressed in terms of the selling price or value of property, the focus of the current study.

Regression models, particularly hedonic models that consider location, structural, and vegetative characteristics, are useful in understanding the relationship between property value and trees or open space. Studies regarding selling price offer insight to the value of greenspace broadly and its relationship to lot size and location, the value of landscaping, and finally, the value of preservation of existing tree canopy or mature trees.

Several studies have considered the "greenness" of neighborhoods, meaning the proportion of trees and other plant material in residential communities. Using the Normalized Difference Vegetation Index, which is derived from $30 \mathrm{~m}$ Landsat imagery, and included as an independent variable in a hedonic model, two studies [one based in North Carolina, U.S. (Mansfield et al. 2005) and the other in Indiana, U.S. (Payton et al. 2008)] found that in most cases, an increase in the amount of vegetation in a residential neighborhood adds value to the parcel. Not all greenspaces, however, are viewed equally or even as assets. In the North Carolina study, it was found that the ownership and land use of a greenspace can determine whether the property acts as a positive or negative contributor to adjacent residential property values.

When considering the contributory value of trees and green space to real estate value, it is increasingly evident that not all trees (or spaces) are equal. Researchers in Denmark (Panduro and Veie 2013) categorized green space into eight different types, and using hedonic models quantified each type's impact on housing prices. Results indicated that "greenspace is not a uniform environmental amenity, but rather a set of distinct goods with very different impacts on housing price." Parks and lakes are associated with a large price premium. Sports fields and agricultural fields were found to have no significant effect. Nature areas were found to have a small price premium. The effect on value for common spaces differed between apartments (significant positive) and houses (not significant). Green buffers designed to shield residential areas from industrial areas or infrastructure were actually found to have a negative effect on housing pricing particularly if the green buffer was poorly maintained. Payton and Ottensmann (2015) considered housing prices in reference to proximity to public parks and greenways, which was found to vary depending on broader neighborhood contexts. Further, Sander (2016) modeled landscape changes over time that are positively associated with housing price to estimate changes in house values as input to land-use planning decisions.

A study conducted in the Washington, D.C., U.S., area compared real estate value for traditional large-lot residential development to small-lot cluster development accompanied by preservation of open space. Researchers found that private acreage (a larger lot) positively affects prices but so does subdivision open spacepossibly substituting for private lot size. Having a lot in a cluster development that is adjacent to subdivision open space appears to enhance the value of the house. Hedonic modeling is used to simulate the effects on prices. Results suggest average house prices are slightly lower with the clustering, particularly for lots not adjacent to open space (Kopits et al. 2007). A similar study based in Iowa, U.S., also found "significant positive marginal effects due to the presence of open space/ conservation features" (Bowman et al. 2009).

Do the environmental and economic benefits of conservation development that preserves open space at the expense of individual lot size offset the costs, including the perceived reduction in value of smaller-sized parcels? A study conducted in Rhode Island, U.S., considered the costs and benefits of conservation subdivisions as compared to conventional subdivisions. Variables, including price premiums, investment costs, and absorption rates, were analyzed using ordinary least squares regression and analysis of covariance to investigate price per acre of developed lots. Results showed that lots in conservation subdivisions carry a premium, are less expensive to build, and sell more quickly than conventional subdivisions (Mohamed 2006).

Regarding the effect of trees on property value expressed as sales price, in most cases, the presence of well-maintained landscape trees that are properly located around residential homes, commercial businesses, and even office properties are considered assets, and contribute favorably to 
the value of the real estate (Laverne and WinsonGeideman 2003). A study conducted in Athens, Georgia, U.S., found that the presence of landscape trees contributed approximately $3.5 \%$ to $4.5 \%$ to the selling price. Researchers found that intermediate- to large-sized landscape trees contributed more than smaller trees regardless of species (Anderson and Cordell 1988). A more recent study conducted in Quebec City, Quebec, Canada, identified 31 attributes of trees and the surrounding landscape that were used as variables within a hedonic model to test the strength of their influence on real estate selling price. The findings suggested that quality landscaping that includes trees, shrubs, turf, or other landscape plants contribute favorably to residential property selling price, providing tree cover was not too dense (Des Rosiers et al. 2002). The current study focuses on the preservation of existing tree canopy and/or mature trees, which could make planting efforts more cost effective (McPherson et al. 2006; Young 2011).

In terms of tree canopy, and closer to the study area, a study in Cincinnati, Ohio, considered percent tree canopy as it relates to residential property values. Using the hedonic method of analysis, researchers found that a one percent increase in tree canopy cover led to an increase of USD $\$ 780$ in property value. Considering the mean tree canopy cover of $25.8 \%$, this study suggests that the average value of tree canopy equals $10.7 \%$ of the sale price of a home (Dimke et al. 2013). Using a hedonic regression model for considering changes to tree and shrub cover, while adding or subtracting turf, Escobedo et al. (2015) reported an average property value increase of $\$ 1,586$ per added tree, while a loss in value occurs as the percentage of maintained turf increases, in four Florida, U.S., communities. Des Rosiers et al. (2002) found that if, however, a higher percent canopy cover was visible from the property than exists on the property itself, the effect on property value is negative.

Another way of considering the value of trees to residential property is to elicit the views of homeowners on what they find to be favorable and unfavorable about landscape trees. A study in State College, Pennsylvania, U.S. (Gorman 2004) found that surveyed homeowners reported increased property value among several positive features of landscape trees. Thirty-six percent of respondents stated a willingness to contribute money toward the establishment and maintenance of street trees, although the report does not indicate the dollar amount that residents would willingly contribute. Bowman et al. (2009) also surveyed homeowners in Iowa, and found that respondents were willing to pay for additional open space features. A concern with willingness-to-pay studies are that they do not actually measure behavior.

\section{MATERIALS AND METHODS}

\section{Research Questions}

The research questions focused on determining the economic value associated with tree preservation, not the addition of landscape trees, on newly developed forested or farmland properties, expressed in terms of house sale price. The study makes a contribution to the literature in this particular aspect of tree value. Researchers sought to understand whether housing sale price had been influenced by tree canopy and the presence of mature trees measured quantitatively. More specifically:

1. What is the influence of preserved trees on home sale prices on a given parcel?

2. What are the challenges to tree preservation, and what are developer's perceptions of the market regarding mature trees and canopy?

3. What are the perceptions of real estate professionals (as a proxy for homebuyers) in the region about mature trees and canopy?

\section{Research Design}

The research design combined quantitative and qualitative methods to gather and analyze useful information in an Ohio context. The quantitative aspect used data obtained through aerial imagery of tree canopy, Google Earth ${ }^{\mathrm{Tm}}$ mapping imagery to identify residential developments, and existing databases of auditors' sale price and home characteristics. The advantage of using Google Earth imagery for determining tree canopy cover is the relatively current nature of the images, the leaf-on seasonal coverage, and the cost (free). The use of Google Earth imag- 
ery for this purpose is consistent with a rapidly growing number of studies, including Jiang et al. (2015). The qualitative methods consisted of guided interviews with residential developers and real estate agents. Researchers sought to understand home buyer behavior as observed by real estate agents, and also regional home markets, as observed by residential developers. These professionals tend to know what types of housing sells, as buyer behavior and market strengths are both indicators of home buyer preferences.

This approach allowed for the development of a nuanced and comprehensive understanding of the economic value that may accrue as a result of tree preservation, as well as challenges to implementing tree preservation in the home development market.

\section{Methods}

Researchers determined a multi-county case study was appropriate for understanding the combination of research questions (providing a large enough real estate market and a variety of landscape/ land cover settings). The Cleveland region was chosen for the study to provide greater access to land development and real estate professionals for qualitative methods selected for the study. Five counties in the Cleveland-Elyria-Mentor Metropolitan Statistical Area (MSA), plus Summit County (part of the Akron MSA), were used in the study. The conceptual model for the study research design is presented in Figure 2, a conceptual but not a chronological depiction.

The objective for the quantitative data was to identify data acquisition methods using digitized and web-based technology that could provide information without relying on data from local governments, given the weak planning requirements in the state. Qualitative data from the real estate and development sectors provided infor- mation on their professional experiences on how the market values preserved trees. The interviews were conducted in parallel, chronologically, with the initial modeling and mapping effortparticularly Model A, the base model. During routine meetings and discussions of the entire team (working on both the quantitative and qualitative portions of the study), other formulations of the regression model were suggested, partly from regular feedback on preliminary findings, and partly as a result of the qualitative findings that were beginning to take shape. Models B and C, and the efforts detailed under "Additional Regression Explorations," came out of those discussions.

\section{Quantitative analysis}

Three hedonic models were specified to answer research question \#1. The database for the modeling consisted of sales and property characteristics files from county administrative databases, reconciled across different counties, which were then filtered to include only single family and condominium sales, only the first sale after the house was built, and only sales to individual buyers (as compared to other developers, LLCs, etc.). After this data cleaning, nearly 3,100 residential units were identified for analysis during the 2009-2011 study period. The right-most column of Table 1 presents new construction home sales by county in the study area. Figure 1 presents the housing sale locations in the six counties.

In terms of quantitative data considerations, issues of tree canopy, dominance, and location were considered. For the parcels with new construction home sales during the study period, researchers sought to know the influence of preserved trees on the sale price. This is differentiated from the value attributed to landscaping that was added to the parcel during the site construction process. The identifica-

Table 1. Tree canopy of new home sales by county, 2009-2011.

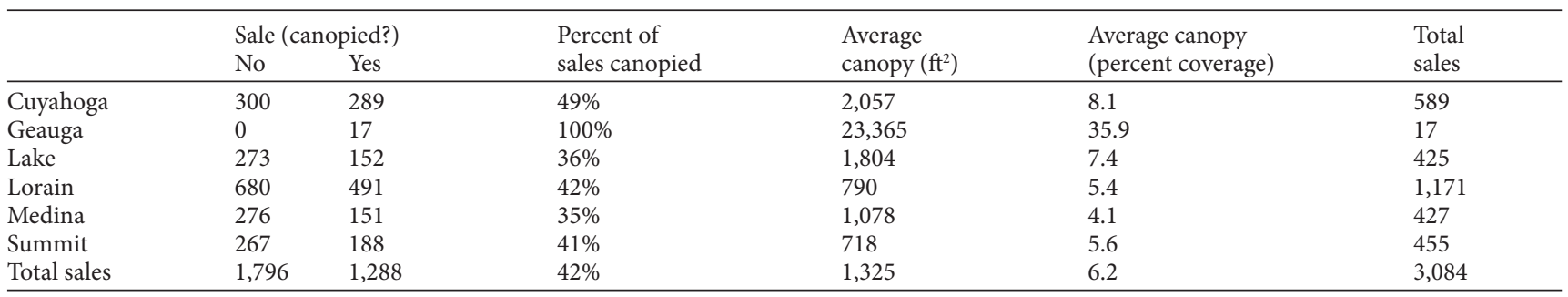




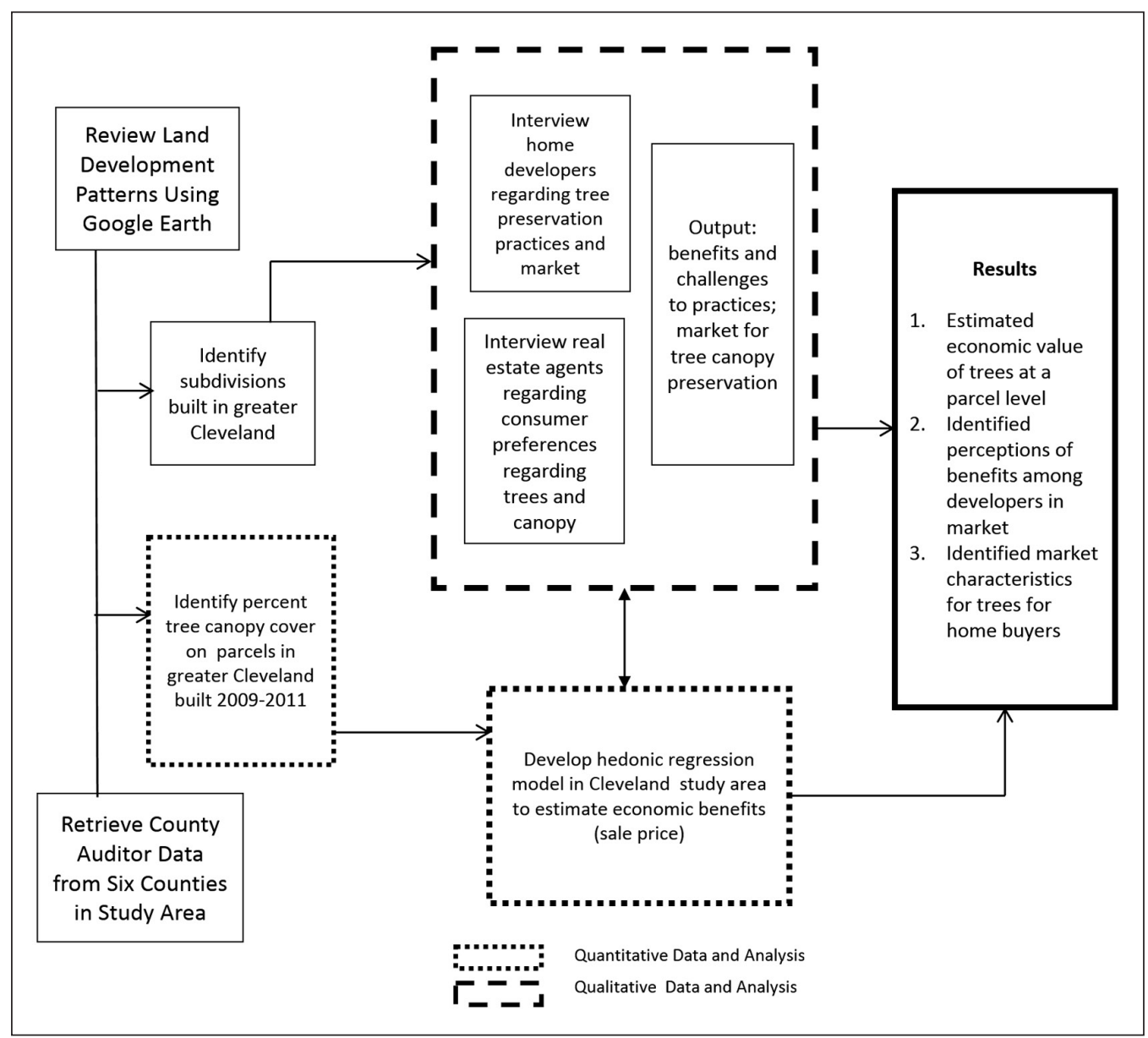

Figure 2. Research design.

tion of trees as preserved in present day canopy was deduced the following way. Given that the study period was for three years, it was reasoned that any trees added during site development would have not achieved a canopy spread of much significance. Thus the model used a percentage of canopy that was deemed reasonable to represent trees that had been growing prior to the development of the land as housing as a proxy for pre-development presence of trees.

The tree cover analysis component of the project involved measuring tree canopy cover in residential neighborhoods from aerial imagery. The imagery came from two sources: Google Earth and the Natural Arboriculture Imagey Program (NAIP). The Google Earth aerial imagery is visible color taken in various seasons (leaf on or leaf off). The NAIP imagery includes a near-infrared band and is taken during the growing season (leaf on), which improves the ability to detect and map tree canopy cover. The tree canopy cover component of the study was completed as follows:

1. The list of residential properties (as previously described) was provided to The Davey Resource Group, where they were matched with parcel records in Google Earth imagery.

2. The Google Earth imagery parcel records were then used to cross-reference parcels in the NAIP color-infrared imagery.

3. An automated image analysis program was used to measure the percent tree canopy cover for each residential property located on the NAIP aerial imagery.

4. Following completion of the automated image analysis, trained image interpreters inspected the tree canopy cover results. The tree canopies identified on the NAIP imagery were then transferred back to the Google imagery and combined with the parcel data. 
(A full description of the process is available from the authors upon request.)

The use of aerial imagery, including the color infrared images acquired through the NAIP, and the use of an automated image analysis program to measure tree canopy cover is consistent with the methods used in conjunction with the U.S. Forests Service i-Tree Eco program for estimating ecosystem values of urban forests (iTree 2017).

The history of land development in the region described may have implications for canopy cover. Table 1 shows that only $42 \%(1,288$ of 3,084$)$ of sales in the data have any tree canopy at all. Except for Geauga County, which had only 17 sales (all of which were canopied), canopy ranges from $35 \%$ of all sales (in Medina County) to $49 \%$ of all sales (in Cuyahoga County). The average canopy square footage and percent are also shown for the sales in each county. Again, excepting the 17 sales of Geauga County, average canopy square footage and percent ranged from 718 to $2057 \mathrm{ft}^{2}$ (66.7 to $191.1 \mathrm{~m}^{2}$ ) and from $4.1 \%$ to $8.1 \%$, respectively.

The Great Recession and its impact on housing is one limitation of the current study. Researchers limited the study to years after the housing crash and before the market in northeastern Ohio began to recover, using data from 2009 to 2011, which are not "typical" years for housing development in the region but are considered more consistent.

\section{Qualitative methods}

To answer research questions \#2 and \#3, two pools of professionals were targeted for the study: real estate agents and housing developers. Researchers sought experts with deep experience and knowledge in the home building and sales industry in the study area, seeking a small number of very qualified and knowledgeable professionals to provide information that would supplement the larger quantitative analysis.

The original methodology planned included focus groups with developers actively working on projects, to provide a nuanced and more comprehensive understanding of the economic value and cost savings that they view as a result of tree preservation. The primary source for developers was a list of 55 developers active between 2007 and 2012 in major development projects seeking stormwater permits in northeastern Ohio, obtained from the Ohio Environmental Protection Agency and county Soil and Water Conservation Districts. This was supplemented with a scan of media coverage of development projects and lists from development member organizations. Each developer on the list was contacted via e-mail and telephone and invited to participate in a focus group. Their response indicated a reluctance to share cost-benefit assessments on their projects with other developers in a focus group setting. The methodology then shifted to one-on-one interviews (both in-person and via telephone), which were more palatable to the developers. Two researchers were present for each interview. Developers were asked to comment on the types of development they build, the locations, local and state regulations, the benefits and challenges related to preservation of trees, and the overall market demand for mature trees/tree canopy as reflected in their subdivision designs and practices. Out of a list of 55 developers active in northeastern Ohio, 29 developers were subsequently identified who had built many of the 184 subdivisions observed during the study period. From this pool, five residential developers, whose companies build housing throughout the study area, agreed to an extensive interview regarding their business practices and the Cleveland market.

To identify realtors, researchers contacted the Ohio Board of Realtors to assist in identifying who in their membership would be most qualified to be interviewed. Researchers had originally considered focus groups, but the study was conducted during peak home sale season, which constrained their ability to participate. Instead, interviews with realtors were conducted by telephone to accommodate their schedules, which limited researchers' ability to record the interviews. Notes were recorded by hand during these interviews. The realtor interviews were intended to complement the data and information collected from the developer interviews regarding home buyer perceptions and behaviors. The small number of interviews were reviewed for themes and summarized. To ensure reliability, two research team members reviewed both realtor and developer interview notes to ascertain any common themes in the responses of these two professional communities of practice. 


\section{RESULTS AND DISCUSSION}

\section{Quantitative Analysis: Housing Value and Canopy}

Regression analysis was used to explore the relationship between tree canopy and the price of newly constructed housing in the study area between 2009 and 2011. The modeling strategy was to first identify a satisfactory base model. The variables included in the base model, and all subsequent regression analyses, fall into three general categories:

1. Data about the house: year built, lot size, living area, rooms, and baths.

2. Data about the neighborhood: density, demographics, housing conditions, and school district quality.

3. Data about location and accessibility: county, proximity to jobs, highways, and the county seat.

Once a base model was identified, researchers explored the price impact of tree canopy in several ways. It is an important modeling distinction that the regression process in this regard was exploratory. Researchers did not enter the modeling process to test a well-formulated expectation of the manner in which, or the degree to which, trees or tree canopy might impact house price. In particular, while previous research identifies the advantages of having some canopy, the current study didn't anticipate those advantages holding equally throughout the full range of possible canopy (that is, $1 \%$ to $100 \%$ canopy). Thus, several models were tested. The two primary canopy variables tested were the square footage of the lot that was covered by tree canopy, and the percent of the lot that was covered by tree canopy, using data derived through NAIP. A description of the data used in the regression modeling is given in Table 2, along with their sources, the abbreviations used in the regression results, and their descriptive statistics.

Present here are three variations on the modeling exercise. Model A estimates the relationship between canopy and housing value across the entire study area in aggregate. Model B explores this relationship county by county. Model C investigates disparate impacts across large and small lots to capture the effect on compact and non-compact development.

\section{Model A (canopy size and canopy coverage)}

Table 3 shows the results of Model A, the first to include measures of tree canopy. County indicator variables are included to account for differences in the average price level by county. The structural characteristics of the house perform as expected. The size of the lot, the amount of livable area in the house, the number of rooms, and the number of bathrooms are all positive and significant. This means that the greater the amount of these variables, the higher the associated sale price. Neighborhood variables are included to account for the influence of the various conditions that surround the sold house. Higher neighborhood education levels are associated with higher prices, which could reflect an underlying relationship between education and income.

The presence of vacant housing is not significant in the model, and the impact of renter occupancy, although small, is positive and significant. Interestingly, in the context of new development, the higher the neighborhood population density, the higher the selling price of the home. This is likely contrary to the perception of sprawling, low density, high priced, exurban development, in that all things being equal, new construction yielded a higher price in higher density neighborhoods. It is important to note, however, this does not reflect the density of the housing development itself, but that of its entire neighborhood. And given the timing of the census data, relative to the time of the study, it is likely that the density measurement excludes the newly constructed home.

The measures of school district quality are aligned qualitatively, relative to the left-out category of Academic Watch/Continuous Improvement, but their significance varies. Similarly, the access to jobs measure is positive but not significant, while access to the nearest highway ramp and county seat are both significant.

The analysis shows that both measures of canopy used-square footage and percentage-are significant. The square footage of canopy is positive and significant, indicating that tree canopy is valued. Higher amounts of tree canopy are associated with higher sales prices. Conversely, the percentage of the lot covered by canopy is negative. Taken together, these forces work in opposition to each other: for a particular lot, the more canopy it 
Table 2. Data for regression modeling with information sources and descriptive statistics.

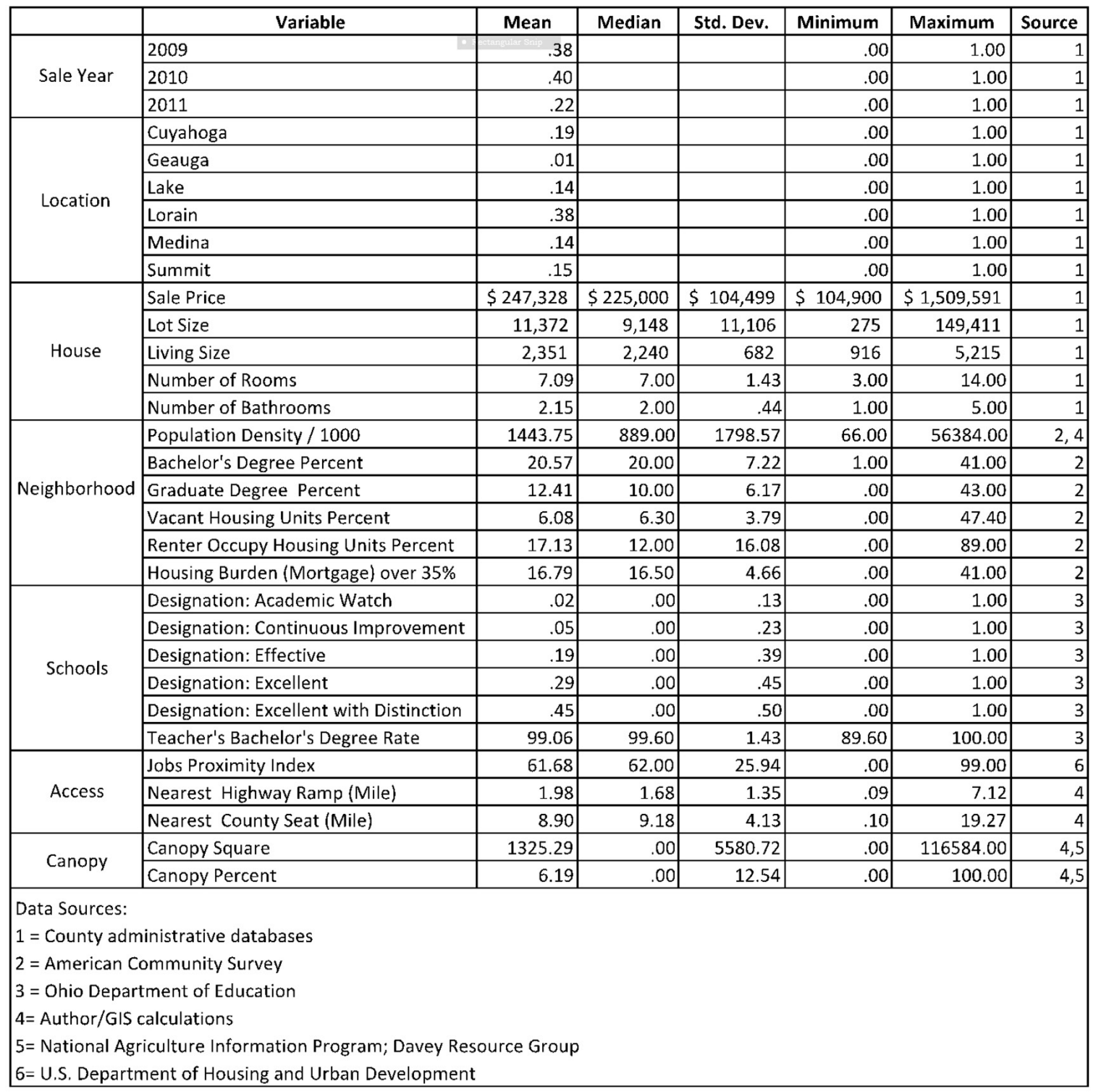

has, the larger the percentage of the lot it covers. In practical terms, it means that households value canopy (higher levels of canopy are associated with higher sales prices), but prefer the canopy to comprise a small percentage of their overall lot (higher percentages of canopy coverage are associated with lower prices). This type of trade-off is not unusual in considering, and valuing, housing attributes. Different aspects of the size of a house might be valued similarly. For example, the floor size (square feet) of the house could be positive, while the number of rooms is negative. This simply means that for a given size of house (square feet), purchasers prefer fewer (and thus larger) rooms. For the find- ings at hand, the explanation is similar. For a given size of canopy (square feet), purchasers prefer it to occupy a smaller portion of their overall lot.

This finding of both positive and negative impacts is consistent with the two Quebec City studies described in the literature review. While one study (Des Rosiers, et al. 2002) found varying impacts comparing site and proximate canopy, the other (Thériault et al. 2002) focused on survey results of purchasers attaching a wide range (both positive and negative) of value to the presence of trees.

Model A indicates that a $1 \%$ increase in canopy (square feet) is associated with a $1 \%$ increase in price. On the other hand, a $1 \%$ 
Table 3. Model A regression results for tree canopy size and tree canopy coverage.

\begin{tabular}{|c|c|c|c|c|c|c|}
\hline \multirow[b]{3}{*}{ Variable Group } & \multirow[b]{2}{*}{ Variable } & \multicolumn{2}{|c|}{$\begin{array}{l}\text { Unstandardized } \\
\text { Coefficients }\end{array}$} & \multirow{2}{*}{$\begin{array}{c}\begin{array}{c}\text { Standardized } \\
\text { Coefficients }\end{array} \\
\text { Beta } \\
\end{array}$} & \multirow[b]{2}{*}{$\mathrm{t}$} & \multirow[b]{2}{*}{ Sig. } \\
\hline & & $\mathrm{B}$ & Std. Error & & & \\
\hline & (Constant) & 5.222 & .301 & & 17.374 & .000 \\
\hline \multirow{5}{*}{ County } & Geauga & .003 & .051 & .001 & .051 & .959 \\
\hline & Lake & .069 & .015 & .070 & 4.482 & .000 \\
\hline & Lorain & -.055 & .013 & -.078 & -4.251 & .000 \\
\hline & Medina & -.073 & .018 & -.074 & -4.046 & .000 \\
\hline & Summit & -.158 & .015 & -.165 & -10.797 & .000 \\
\hline \multirow{6}{*}{ House } & Lot Size Natural Log & .114 & .007 & .257 & 17.474 & .000 \\
\hline & Living Size Natural Log & .404 & .017 & .334 & 23.570 & .000 \\
\hline & Number of Rooms & .016 & .003 & .068 & 4.907 & .000 \\
\hline & Number of Bathrooms & .132 & .008 & .173 & 15.576 & .000 \\
\hline & Built Year 2010 & .028 & .008 & .040 & 3.296 & .001 \\
\hline & Built Year 2011 & .023 & .011 & .029 & 2.137 & .033 \\
\hline \multirow{6}{*}{ Neighborhood } & Population Density / 1000 & .022 & .003 & .115 & 8.445 & .000 \\
\hline & Bachelor's Degree Percent & .007 & .001 & .147 & 7.679 & .000 \\
\hline & Graduate School Degree (MA, PH, PRO) Percent & .012 & .001 & .217 & 11.289 & .000 \\
\hline & Vacant Housing Units Percent & -.002 & .001 & -.019 & -1.473 & .141 \\
\hline & Renter Occupancy Percent & .002 & .000 & .079 & 5.366 & .000 \\
\hline & Housing Burden (Mortgage) over 35\% & .006 & .001 & .084 & 6.984 & .000 \\
\hline \multirow{4}{*}{ Schools } & Designation Effective & .008 & .019 & .009 & .431 & .666 \\
\hline & Designation Excellent & .030 & .019 & .041 & 1.639 & .101 \\
\hline & Designation Excellent with Distinction & .034 & .018 & .050 & 1.848 & .065 \\
\hline & Teacher's Bachelor's Degree Rate & .020 & .003 & .084 & 7.337 & .000 \\
\hline \multirow{5}{*}{ Access } & Access to the Nearest Highway Ramp (Mile) & -.037 & .009 & -.147 & -4.255 & .000 \\
\hline & Access to the Nearest Highway Ramp (Mile) Square & .006 & .001 & .146 & 4.336 & .000 \\
\hline & Access to the Nearest County Seat (Mile) & .037 & .004 & .454 & 8.508 & .000 \\
\hline & Access to the Nearest County Seat (Mile) Square & -.002 & .000 & -.382 & -7.280 & .000 \\
\hline & Job Accessibility Index & .00024 & .00015 & .018 & 1.525 & .127 \\
\hline \multirow{2}{*}{ Canopy } & Canopy Square Natural Log & .010 & .003 & .105 & 3.996 & .000 \\
\hline & Canopy Percent Natural Log & -.024 & .007 & -.093 & -3.650 & .000 \\
\hline
\end{tabular}

Adjusted R-squared: 0.689 / F: 244.423

increase in canopy coverage (as a percentage of the lot) is associated with a $2.4 \%$ decrease in price. What do these opposing impacts mean for an average sale in the study region?

The average sold house in the study has approximately $1,325 \mathrm{ft}^{2}\left(123.1 \mathrm{~m}^{2}\right)$ of canopy, covering approximately $6.2 \%$ of the lot. The combined predicted price change associated with a $1 \%$ increase in both canopy measures is 3\% of house price, or \$7,298, based on an average priced house in the study region. Considering a fixed amount of canopy (square feet), that canopy is most valuable if it covers the smallest percentage of the lot. For example, for a house with the average amount of canopy $\left(1,325 \mathrm{ft}^{2} / 123.1 \mathrm{~m}^{2}\right)$, the price impact of an additional $1 \%$ of canopy coverage is a $6 \%$ increase in price if it comprises $2 \%$ of the total lot; it is worth $3 \%$ price increase if it covers $5 \%$ of the lot, and actually has a negative price impact once the canopy covers more than roughly $21 \%$ of the total lot. The same type of relationship holds when considering a fixed percentage of tree canopy. For a house with average canopy coverage $(6.2 \%)$, a $1 \%$ addition is valued at $2 \%$ if the total canopy covers $750 \mathrm{ft}^{2}\left(699.7 \mathrm{~m}^{2}\right)$, but $4 \%$ if it covers 2,500 $\mathrm{ft}^{2}\left(232.3 \mathrm{~m}^{2}\right)$. This type of trade-off was the most consistent finding throughout the various regression analyses conducted. Experimenting with different measurement approaches, interaction variables, and/or different variables, and/or different subsets of the data, the positive effect on price of canopy size and the negative effect on price of percent canopy coverage emerged as the dominant, although not universal, relationships in the data. It is a similar finding to Escobedo et al. (2015), who found significant positive price impacts of individual trees (similar to the measure of square feet of canopy), although their negative impact of finished turf is likely dissimilar to the negative impact of percent canopy (assuming percent canopy and percent finished turf work in opposition to each other). 


\section{Model B (county-specific findings)}

Model B explored the degree to which these aggregate canopy impacts varied by county within the study area. Thus, interaction variables were created between the county indicator variables and the two canopy predictors. The result is a canopy percent and canopy square footage effect estimated for each county individually, but still within a single regression model. Operating from the concept of scarcity, the expectation was that canopy might be worth more in locations where canopy was less common, and worth less in counties where canopy was commonplace. Table 4 shows the results from Model B. Focusing on the canopy results, the percent canopy and square feet of canopy variables attain traditional levels of significance $(<0.05)$ in only two counties: Medina and Summit. With regard to Medina, the expectation was correct-the value of canopy is significant in the county where the lowest proportion of sales is canopied. A $1 \%$ increase in canopy coverage is associated with a 3.3\% decrease in house price, while a $1 \%$ increase in canopy (square feet) is associated with a $1.9 \%$ increase in sales price. Considering the average values for Medina canopy $\left[1,078 \mathrm{ft}^{2}\left(100.1 \mathrm{~m}^{2}\right)\right.$ and $4.1 \%$ coverage], the net price impact of a $1 \%$ increase in percent coverage, and square footage is $8 \%$. This total impact is approaching the $10.7 \%$ price premium associated with tree canopy in the previously referenced Cincinnati study (Dimke et al. 2013).

Table 4. Model B regression results for county-specific findings.

\begin{tabular}{|c|c|c|c|c|c|c|}
\hline \multirow[b]{3}{*}{ Variable Group } & \multirow[b]{2}{*}{ Model B } & \multicolumn{2}{|c|}{$\begin{array}{l}\text { Unstandardized } \\
\text { Coefficients }\end{array}$} & \multirow{2}{*}{$\begin{array}{c}\begin{array}{c}\text { Standardized } \\
\text { Coefficients }\end{array} \\
\text { Beta }\end{array}$} & \multirow[b]{2}{*}{$\mathrm{t}$} & \multirow[b]{2}{*}{ Sig. } \\
\hline & & $\mathrm{B}$ & Std. Error & & & \\
\hline & (Constant) & 5.130 & .304 & & 16.855 & .000 \\
\hline \multirow{5}{*}{ County } & Geauga & .406 & .332 & .088 & 1.222 & .222 \\
\hline & Lake & .101 & .019 & .103 & 5.392 & .000 \\
\hline & Lorain & -.031 & .016 & -.044 & -1.921 & .055 \\
\hline & Medina & -.078 & .021 & -.079 & -3.713 & .000 \\
\hline & Summit & -.153 & .018 & -.160 & -8.414 & .000 \\
\hline \multirow{6}{*}{ House } & Lot Size Natural Log & .114 & .007 & .258 & 17.154 & .000 \\
\hline & Living Size Natural Log & .400 & .017 & .331 & 23.233 & .000 \\
\hline & Number of Rooms & .016 & .003 & .069 & 4.983 & .000 \\
\hline & Number of Bathrooms & .129 & .009 & .169 & 15.204 & .000 \\
\hline & Built Year 2010 & .026 & .009 & .037 & 2.999 & .003 \\
\hline & Built Year 2011 & .021 & .011 & .026 & 1.940 & .052 \\
\hline \multirow{6}{*}{ Neighborhood } & Population Density / 1000 & .022 & .003 & .114 & 8.397 & .000 \\
\hline & Bachelor's Degree Percent & .007 & .001 & .157 & 8.182 & .000 \\
\hline & Graduate school Degree (MA, PH, PRO) Percent & .012 & .001 & .220 & 11.427 & .000 \\
\hline & Vacant Housing Units Percent & -.002 & .001 & -.021 & -1.695 & .090 \\
\hline & Renter Occupied Housing Units Percent & .002 & .000 & .079 & 5.340 & .000 \\
\hline & Housing Burden (Mortgage) over $35 \%$ & .006 & .001 & .081 & 6.727 & .000 \\
\hline \multirow{4}{*}{ Schools } & Designation Effective & .004 & .019 & .005 & .230 & .818 \\
\hline & Designation Excellent & .022 & .019 & .029 & 1.180 & .238 \\
\hline & Designation Excellent with Distinction & .026 & .019 & .038 & 1.416 & .157 \\
\hline & Teacher's Bachelor's Degree Rate & .021 & .003 & .088 & 7.595 & .000 \\
\hline \multirow{5}{*}{ Access } & Access to the Nearest Highway Ramp (Mile) & -.040 & .009 & -.158 & -4.552 & .000 \\
\hline & Access to the Nearest Highway Ramp (Mile) Square & .007 & .001 & .160 & 4.733 & .000 \\
\hline & Access to the Nearest County Seat (Mile) & .040 & .004 & .482 & 8.987 & .000 \\
\hline & Access to the Nearest County Seat (Mile) Square & -.002 & .000 & -.410 & -7.772 & .000 \\
\hline & Job Accessibility Index & .00022 & .00016 & .017 & 1.410 & .159 \\
\hline \multirow{6}{*}{$\begin{array}{c}\text { Canopy (Percent, } \\
\text { Natural Log) }\end{array}$} & Cuyahoga & .004 & .014 & .009 & .288 & .773 \\
\hline & Geauga & .099 & .059 & .070 & 1.682 & .093 \\
\hline & Lake & -.029 & .019 & -.051 & -1.468 & .142 \\
\hline & Lorain & -.009 & .007 & -.023 & -1.167 & .243 \\
\hline & Medina & -.033 & .014 & -.046 & -2.277 & .023 \\
\hline & Summit & -.053 & .013 & -.091 & -4.144 & .000 \\
\hline \multirow{6}{*}{$\begin{array}{l}\text { Canopy (Square } \\
\text { Feet, Natural Log) }\end{array}$} & Cuyahoga & .005 & .005 & .031 & .945 & .345 \\
\hline & Geauga & -.072 & .052 & -.143 & -1.397 & .162 \\
\hline & Lake & .006 & .007 & .027 & .739 & .460 \\
\hline & Lorain & .001 & .003 & .010 & .443 & .658 \\
\hline & Medina & .019 & .005 & .079 & 3.573 & .000 \\
\hline & Summit & .021 & .005 & .101 & 4.192 & .000 \\
\hline
\end{tabular}


Table 5. Model C regression results for residential lot size.

\begin{tabular}{|c|c|c|c|c|c|c|}
\hline \multirow{3}{*}{$\begin{array}{c}\text { Variable } \\
\text { Characteristics }\end{array}$} & \multirow[b]{2}{*}{ Model } & \multicolumn{2}{|c|}{ Unstandardized Coefficients } & \multirow{2}{*}{$\begin{array}{c}\begin{array}{c}\text { Standardized } \\
\text { Coefficients }\end{array} \\
\text { Beta } \\
\end{array}$} & \multirow[b]{2}{*}{$\mathrm{t}$} & \multirow[b]{2}{*}{ Sig. } \\
\hline & & $\mathrm{B}$ & Std. Error & & & \\
\hline & (Constant) & 5.526 & .304 & & 18.198 & .000 \\
\hline \multirow{5}{*}{ County } & Geauga & -.002 & .050 & .000 & -.033 & .974 \\
\hline & Lake & .063 & .015 & .064 & 4.135 & .000 \\
\hline & Lorain & -.055 & .013 & -.078 & -4.270 & .000 \\
\hline & Medina & -.070 & .018 & -.071 & -3.921 & .000 \\
\hline & Summit & -.158 & .015 & -.164 & -10.774 & .000 \\
\hline \multirow{6}{*}{ House } & Lot Size Natural Log & .104 & .007 & .234 & 15.401 & .000 \\
\hline & Living Size Natural Log & .397 & .017 & .329 & 23.267 & .000 \\
\hline & Number of Rooms & .016 & .003 & .067 & 4.860 & .000 \\
\hline & Number of Bathrooms & .131 & .008 & .171 & 15.464 & .000 \\
\hline & Built Year 2010 & .029 & .008 & .041 & 3.396 & .001 \\
\hline & Built Year 2011 & .027 & .011 & .033 & 2.466 & .014 \\
\hline \multirow{6}{*}{ Neighborhood } & Population Density / 1000 & .022 & .003 & .114 & 8.456 & .000 \\
\hline & Bachelor's Degree Percent & .007 & .001 & .142 & 7.433 & .000 \\
\hline & Graduate school Degree (MA, PH, PRO) Percent & .012 & .001 & .222 & 11.548 & .000 \\
\hline & Vacant Housing Units Percent & -.001 & .001 & -.016 & -1.277 & .202 \\
\hline & Renter Occupied Housing Units Percent & .002 & .000 & .076 & 5.179 & .000 \\
\hline & Housing Burden (Mortgage) over $35 \%$ & .006 & .001 & .085 & 7.110 & .000 \\
\hline \multirow{4}{*}{ Schools } & Designation Effective & .010 & .019 & .012 & .552 & .581 \\
\hline & Designation Excellent & .032 & .019 & .042 & 1.707 & .088 \\
\hline & Designation Excellent with Distinction & .033 & .018 & .048 & 1.771 & .077 \\
\hline & Teacher's Bachelor's Degree Rate & .018 & .003 & .077 & 6.752 & .000 \\
\hline \multirow{5}{*}{ Access } & Access to the Nearest Highway Ramp (Mile) & -.035 & .009 & -.140 & -4.058 & .000 \\
\hline & Access to the Nearest Highway Ramp (Mile) Square & .006 & .001 & .139 & 4.155 & .000 \\
\hline & Access to the Nearest County Seat (Mile) & .037 & .004 & .455 & 8.551 & .000 \\
\hline & Access to the Nearest County Seat (Mile) Square & -.002 & .000 & -.383 & -7.326 & .000 \\
\hline & Job Accessibility Index & .00020 & .00015 & .015 & 1.279 & .201 \\
\hline \multirow{4}{*}{ Canopy } & Canopy square feet (Large Lot) & .012 & .003 & .122 & 4.421 & .000 \\
\hline & Canopy percent (Large Lot) & -.021 & .007 & -.076 & -2.868 & .004 \\
\hline & Canopy square feet (Small Lot) & -.004 & .006 & -.018 & -.608 & .543 \\
\hline & Canopy percent (Small Lot) & -.015 & .015 & -.029 & -.996 & .320 \\
\hline
\end{tabular}

Adjusted R-squared: 0.692 / F: 231.570

The remaining results don't fit neatly into the scarcity argument. Lake County, for example, had only $36 \%$ canopied sales (only $1 \%$ more than the "scarcest" sales of Medina County), and its canopy variables are not significant. Summit County is the only other county to exhibit significant impacts of both canopy variables, yet its percent of canopied sales was close to the average. A $1 \%$ increase in percent coverage is associated with a $5.3 \%$ decrease in price, while prices increased $2.1 \%$ associated with a $1 \%$ increase in canopy (square feet). None of the other counties in the study showed a significant canopy effect, either in square feet or percentage terms.

\section{Model C (lot size)}

Model $\mathrm{C}$ explored differences in the canopy impact between large and small lots. As the break point between large and small lots, researchers used 7,260 $\mathrm{ft}^{2}\left(674.5 \mathrm{~m}^{2}\right)$. This size follows the Ohio Balanced Growth's Best Local Land Use Practices definitions, a program of the Ohio Lake Erie Commis- sion and the impetus for the study. Separate from the regression results, it is a notable finding that a full one-third of all the new construction sales in the six county region from 2009 to 2011 were on lots that fit within the compact development definition used by the Balanced Growth Program.

Large lots, by this definition, comprised 2,040 observations, of which $50.4 \%$ were canopied. Small lots made of up the remaining 1,044 observations, $24.9 \%$ of which were canopied. The expectation of this final regression was that purchasers of smaller lots might not have an expectation of canopy cover, and so canopy might play a smaller role, or even no role, in explaining house price. Table 5 shows the regression results, which confirmed this expectation. The two canopy variables are not significant for small lots, but they are both significant for large lots. For large lots, a $1 \%$ increase in canopy coverage is associated with a $2.1 \%$ decrease in price. A $1 \%$ increase in canopy (square feet) is associated with a $1 \%$ increase in price. For the average large lot sale, then $[1,919$ 
$\mathrm{ft}^{2}\left(178.3 \mathrm{~m}^{2}\right)$ of canopy, representing $7.7 \%$ coverage], its canopy is valued at $5 \%$ of the sale price.

\section{Additional Regression Explorations}

The modeling results led to an effort to identify a more nuanced explanation of the impacts of tree canopy. Other formulations of the canopy-price relationship were explored, but these failed to yield significant findings. First, the presence of a tipping point in the value of canopy cover was explored. A tipping point would be consistent with the thinking that some tree canopy is valued (due to the aesthetic, heating, cooling, or other benefits), but that too much canopy would be a negative influence on price (e.g., lack of sunshine, increased maintenance) (Sander et al. 2010). The study authors did not find evidence of this relationship in the hedonic modeling of the study area.

Similarly, researchers investigated to see whether the amount of canopy mattered not on a percentby-percent basis, or a square-foot-by-squarefoot basis, but on the basis of broad amounts of canopy. The motivation here was thinking that households might not distinguish between $4 \%$ and $6 \%$ canopy, but they might make judgments or have preferences relating to none, some, more than average, or a lot of canopy. Quartiles were used, and modifications of quartiles to approximate these categories. The study authors did not find evidence of this relationship in the study area.

Based on a non-random subset of the sales data, and using supplementary data gleaned from Google Earth, researchers explored the impact on price of tree type, height, and placement for the subdivisions identified as having compact densities. Previous studies that have explored these relationships have used photographic images of the house lot, typically taken from the public right-of-way. Researchers sought a new method for obtaining information about trees on the lot that could be analyzed for economic impact. Site-specific tree characteristics included:

- The relative height of individual trees in one of three categories:

- Dominant over story (mature trees that tower over most others in the landscape);

- Codominant over story (mature trees that are roughly equal in height to other nearby trees); and
- Understory (small-growing mature or immature trees that are shorter than the adjacent house).

- Yard placement - Trees were identified by their placement relative to the house, including street trees (planted along the edge of the street), front yard, side yard, or backyard.

- Tree type - Trees were identified as either conifer (e.g., pine, spruce, fir, hemlock) or broadleaf (e.g., maple, oak, ash, birch).

This process was accomplished by a detailed visual inspection of each parcel in question using Google Earth. Within the mapping service, different aerial views with various axis and zoom settings were used in order to orient the parcel with the lighting at the time the parcel was photographed. Researchers were able to measure and explore the impact of the following attributes: historic land cover (forested or field), density (low or high), and current tree canopy/preservation information. Pre-development land cover was considered "forested" if it had 25\% or more canopy coverage. Trees were considered "preserved" if the canopy on the development site was $4 \%$ or greater.

While none of these regression explorations were fruitful, neither were they systematic, as the subsequent modeling was completed for the parcels located in higher density subdivisions ( 800 parcels). A more rigorous treatment of these relationships, for all 184 subdivisions identified and all parcels, for example, could yield different results. The study authors have, however, developed the method by which this analysis can be accomplished.

\section{Qualitative Analysis: The Value of Trees in the Market \\ Developers}

Developers note that when building larger developments, they do preserve trees, but typically on the periphery of the subdivision, to act as a buffer to other developments or dis-amenities, such as roads. All the developers explained that it is very difficult to preserve trees on more compact (smaller lots) subdivision home sites because construction and infrastructure compact soils and damage tree roots. Unless there is a significant tree or the tree is in a strategic location, they will clear cut on the lots and leave trees on the periphery. This was consis- 
tent with the data used for Model C, which indicated that only $25 \%$ of the small lot sales were canopied, while $50 \%$ of the large lot sale were.

As might be expected, overall development costs and expected return on investment influence the decision about tree preservation. One developer related that for a development in the western part of the study area, he left the trees but had to trim the yield of houses by $15 \%$ ( 48 versus 53 homes) to get quality lots. This created a loss of gross revenue. Time is also a factor. How to design and build out the site is always a function of rate of return, with three considerations: the cost of land, the return to developer/builder, and reduced maintenance cost to governing agencies (sewer authority, municipality, stormwater directed to undeveloped areas). One of the five developers noted that while trees can be viewed as a positive, some people view them as a negative, depending on their size and proximity to the house, noting: "people are afraid large trees may fall on their house," and "there is a mix of homeowners who want mature trees and those who don't."

\section{Real Estate Agents and Homebuyers}

Researchers also interviewed real estate agents, who work in communities across the region, to gain insight on their experiences with potential homebuyers regarding tree preservation. Researchers asked them about trees and tree canopy in developments and whether trees impact buyers' valuation of properties and their decisions to purchase a property. The realtors echoed the messages about trees from the developers. Trees were described as being an attribute that prospective homebuyers desire-“everyone likes trees." Realtors indicated that clients do not like to move into subdivisions where the builder/developer has cut down all the trees, which homebuyers describe as "dull and barren." Even when the builder/developer has put in some landscaping, such as small decorative trees or planted new young trees, having mature trees is viewed as better and more desirable by homebuyers. Agents agreed that there are some people who look specifically for properties with large mature trees.

However, having "really big trees" (the kind most likely perceived as aesthetically appropriate for preservation) can create concern for some buyers. In these cases they are worried about the mainte- nance and cost associated with their care and the overall yard care-“people don't like to rake." Sometimes their concerns are in relation to safety issues, such as trees falling in storms. Agents agreed that the location of trees on a given property might impact a buyer's decision to purchase a property. Mature trees that are close to the house raise concern among buyers (roots damaging foundations, limbs falling on roofs, significant raking). In general, buyers prefer trees to be located in such a way that affords them privacy, most likely in the backyard. Privacy was characterized as being especially important in locations where properties were closer together (most notably in compact developments). In many cases, in compact developments, realtors said having trees would be good to help prevent homebuyers from feeling they were right on top of their neighbors. Surely, it is a mismatch in the findings that realtors report that consumers value trees the most in the exact context where developers say they are hardest to preserve: on small lots.

\section{CONCLUSIONS AND SUMMARY}

Regarding the first research question on the influence of preserved trees on sale price, researchers learned from the analyses that the issue of tree preservation and economic value is nuanced. First, efforts to uncover a systematic relationship between tree canopy and house price resulted in a mixed set of results. Perhaps the most consistent finding was the different ways in which canopy impacted house price. The square feet of canopy had a positive impact on price, while the percent of the lot covered by canopy had a negative impact. Although these canopy variables weren't significant in every regression formulation, when researchers did uncover significance it was typically in this type of positive (square feet) and negative (percent coverage) format. At the same time, while this relationship held for the study area in aggregate, when disaggregated by county and by lot size, results were mixed. As the developers and realtors noted, the home sales market in northeastern Ohio is very localized, and consumer preferences for trees depended much on the context of the house sale.

Regarding the second and third research questions, both developers and realtors noted the difference in perception among homebuyers about mature, preserved trees on lots versus retaining 
these trees in developments. Developers clearly attribute value to the presence of mature trees at gateway areas into the development and as boundaries for the subdivision, but less so in the interior, in part because of the difficulty in overcoming soil compaction under mature trees within the development. This leads them to remove trees on the house lots, where (in the case of compact development) real estate agents say they are valued the most. Developers preserve trees mostly on the periphery to act as a buffer. The realtors interviewed confirmed the economic value of this practice, and confirmed that buyers appreciate the trees as buffers, and like having many trees around the development, but it's the package (i.e., trees in the neighborhood, providing privacy at the boundary) rather than having trees specifically on the home lots, that is appealing. These professionals testify that many buyers do not want mature trees near their house, no matter the other benefits they might provide, in fear of the costs of maintenance or trees falling on their homes.

To encourage a view of tree preservation as an economic benefit, it would make sense to encourage developers to pay attention to the location of trees at the time of site design. Developers prefer to develop where there are trees in adjacent land, but clearly neither the homebuyer nor the realtor know if these trees will exist in the future. That uncertainty may exert a downward pressure on sale price, and would likely affect future sale price if trees on adjacent lots are removed. This uncertainty might be a leverage point to incent developers to leave mature trees at the periphery on the site they control, and if possible, keep trees in stands on the interior of the development so there is visual access to the trees from a majority of parcels.

The research suggests that both economic and environmental value could be found by encouraging the development community to maintain trees in the periphery of subdivisions and along water courses, such as riparian areas, streams, and wetlands. These practices would likely provide the most direct benefits to water resources, while enhancing the value of lots in subdivisions most significantly.

The combined approach, using quantitative sale value and qualitative feedback from development and real estate professionals to understand the significance of tree canopy, enabled research- ers to identify specifically where the value lies in preserving trees. This combination led to a better, if still incomplete understanding of this nuanced market, and a better basis for public policy. There are many future avenues for research.

The work that should come next would explore the nature of those situations where canopy does and does not matter. First, all canopy is not equal in the eyes of buyers, real estate agents or developers. The canopy collected through aerial photos does not differentiate by tree type, meaning that a conifer with a $3 \mathrm{~m}$ diameter canopy that extends to ground level would register much the same as would an oak tree. Future research could use site-specific data using the Google Earth method to distinguish these types of trees, in anticipation that homebuyers might value usable space under a tree canopy differently.

A second research area to explore is to return to the GIS database and rerun the hedonic model so that it captures sales price impacts related to the presence of trees in $100 \mathrm{~m}$ and $200 \mathrm{~m}$ buffers from a given parcel, or at the edge of a development, to ascertain the impact of canopy in proximity to a sale, rather than only on the sold parcel. This would in some way capture the associated value of trees (if any) as perceived by homebuyers at the subdivision level that was suggested by developers and real estate agents. Further modeling on the existing data could be done to incorporate tree canopy data in a series of buffers around the lot, which might capture the notion brought forward by realtors that the presence of trees in the neighborhood at large can affect home value as well. This research would provide quantified levels of economic benefits in Ohio's markets.

Third, future research could investigate whether there is a difference in value (real or perceived) if the percent canopy cover on a parcel is different depending on whether the canopy is continuous/aggregated or fragmented across the site, as this might change use of the property, visual impacts, and therefore, home buyer perceptions.

Clearly, additional research is warranted on this topic before results would form a suitable foundation for specific policy recommendations that might be applied basin-wide or statewide, but what is clear from this quantitative and qualitative work, however, is that canopy does play a significant role in explaining house price varia- 
tions in some situations. The challenge ahead is to continue to refine an understanding of which situations, while providing the development and policy communities the information they need to maximize both the economic and environmental value of both trees and tree preservation.

Acknowledgments. The authors would like to thank Ms. Molly Schnoke and Mr. Charlie Post, staff researchers at Levin College, and students Nat Neider, Caylen Payne, and Minkyu Yeom for their assistance on this project. This project was funded by the Ohio Lake Erie Commission and the Ohio Water Resources Council. All responsibility for content lies with the paper's authors.

\section{LITERATURE CITED}

Akbari, H., M. Pomerantz, and H. Taha. 2001. Cool surfaces and shade trees to reduce energy use and improve air quality in urban areas. Solar Energy 70(3):295-310.

Anderson, L., and H. Cordell. 1988. Influence of trees on residential property values in Athens, Georgia (U.S.A.): A survey based on actual sales prices. Landscape and Urban Planning 15:153-164.

Bier, T. 2001. Urban sprawl and decline: Prospects for change. Public Works Management \& Policy 6(2):83-87.

Bowman, T., J. Thompson, and J. Colletti. 2009. Valuation of open space and conservation features in residential subdivisions. Journal of Environmental Management 90(1):321-330.

Boyle, R., and R. Mohamed. 2007. State growth management, smart growth and urban containment: A review of the U.S. and a study of the heartland. Journal of Environmental Planning \& Management 50(5):677-697.

Des Rosiers, F., M. Thériault, Y. Kestens, and P. Villeneuve. 2002. Landscaping and house values: An empirical investigation. Journal of Real Estate Research 23(1):139-161.

Dimke, K., T. Sydnor, and D. Gardner. 2013. The effect of landscape trees on residential property values of six communities in Cincinnati, Ohio. Arboriculture \& Urban Forestry 39(2):49-55.

Dwyer, J., E. McPherson, H. Schroeder, and R. Rowntree. 1992. Assessing the benefits and costs of the urban forest. Journal of Arboriculture 18(5):227-234.

Escobedo, F., D. Adams, and N. Timilsina. 2015. Urban forest structure effects on property value. Ecosystem Services 12:209-217.

Gorman, J. 2004. Residents' opinions on the value of street trees depending on tree location. Journal of Arboriculture 30(1):36-44.

Hudson, M. 2000. Ground work: Investigating the need for nature in the city, Evergreen. Accessed 18 December 2014. <www.evergreen.ca/downloads/html/ground-work>

iTree. 2017. i-Tree Eco. Tools for assessing and managing forests and community trees. <www.itreetools.org/eco/index.php>

Jeng, H., A. Englande, R. Bakeer, and H. Bradford. 2005. Impact of urban stormwater runoff on estuarine environmental quality. Estuarine, Coastal, and Shelf Science 63(4):513-526.

Jiang, B., L. Larsen, B. Deal, and W.C. Sullivan. 2015. A doseresponse curve describing the relationship between tree cover density and landscape preference. Landscape and Urban Planning 139:16-25. <doi: http://dx.doi.org/10.1016/j.landurbplan. 2015.02.018>
Kellogg, W. 2007. The state role in guiding land use change in the Ohio Lake Erie basin: Key policies, programs, and incentives for the Ohio Balanced Growth Program Final report. Ohio Lake Erie Commission and EcoCity Cleveland, Cleveland, Ohio. 151 pp.

Kopits, E., V. McConnell, and M. Walls. 2007. The trade-off between private lots and public open space in subdivisions at the urban-rural fringe. American Journal of Agricultural Economics 89(5):1191-1197.

Laverne, R., and G. Lewis. 1996. The effect of vegetation on residential energy use in Ann Arbor, Michigan. Journal of Arboriculture 22(5):234-243.

Laverne, R., and K. Winson-Geideman. 2003. The influence of trees and landscaping on rental rates at office buildings. Journal of Arboriculture 29(5):281-290.

Mansfield, C., S.K. Pattanayak, W. McDow, R. McDonald, and P. Halpin. 2005. Shades of Green: Measuring the value of urban forests in the housing market. Journal of Forest Economics 11(3):177-199.

McPherson, E., J. Simpson, P. Peper, S. Gardner, K. Vargas, S. Maco, and Q. Xiao. 2006. Midwest community tree guide: benefits, costs, and strategic planting. General Technical Report PSWGTR-199. U.S. Department of Agriculture, Forest Service, Albany, California, U.S. 85 pp.

Mohamed, R. 2006. The Economics of Conservation Subdivisions: Price Premiums, Improvement Costs, and Absorption Rates. Urban Affairs Review 41(3):376-399.

Nowak, D. 1994. Air pollution removal by Chicago's urban forest. pp. 63-81 In: E.G. McPherson, D.J. Nowak, and R.A. Rowntree (Eds.). Chicago's Urban Forest Ecosystem: Results of the Chicago Urban Forest Climate Project., Gen. Tech. Rep NE-186. USDA Forest Service, Northeastern Forest Experiment Station, Radnor, Pennsylvania, U.S. 201 pp.

Nowak, D., and D. Crane. 2002. Carbon storage and sequestration by urban trees in the USA. Environmental Pollution 116(3):381-389.

Nowak, D., R. Hoehn, and D. Crane. 2007. Oxygen production by urban trees in the United States. Arboriculture \& Urban Forestry 33(3):220-226.

Panduro, T.E., and K.L. Veie 2013. Classification and valuation of urban green spaces: A hedonic house price valuation. Landscape and Urban Planning 120:119-128.

Payton, S., and J. Ottensmann. 2015. The implicit price of urban public parks and greenways: A spatial-contextual approach. Journal of Environmental Planning and Management 58(3):495-512.

Payton, S., G. Lindsey, J. Wilson, J. Ottensmann, and J. Man. 2008. Valuing the benefits of the urban forest: A spatial hedonic approach. Journal of Environmental Planning and Management 51(6):717-736.

Pendall, R. 2003. Sprawl without growth: The upstate paradox. Report of The Brookings Institution/Center on Urban and Metropolitan Policy, Washington, D.C. 11 pp.

Rossi, L., and R. Hari. 2007. Screening procedure to assess the impact of urban stormwater temperature to populations of brown trout in receiving water. Integrated Environmental Assessment and Management 3(3):383-392.

Sander, H. 2016. Assessing impacts on urban greenspace, waterways, and vegetation in urban planning. Journal of Environmental Planning and Management 59(3):461-479. 
Sander, H., S. Polasky, and R. Haight. 2010. The value of urban tree cover: A hedonic property price model in Ramsey and Dakota Counties, Minnesota, USA. Ecological Economics 69(8):1646-1656.

Thériault, M., Y. Kestens, and F. Des Rosiers. 2002. The impact of mature trees on house values and on residential location choices in Quebec City. In: International Environmental Modelling and Software Society. Integrated Assessment and Decision Support. 1st biennial meeting of the International Environmental Modelling and Software Society. University of Lugano, Switzerland. Vol 1. pp. 478-483.

Xiao, Q., and E. McPherson. 2002. Rainfall interception by Santa Monica's municipal urban forest. Urban Ecosystems 6(4):291-302.

Young, R. 2011. Planting the living city. Journal of the American Planning Association 77(4):368-381.

\author{
Wendy Kellogg (corresponding author) \\ Levin College of Urban Affairs \\ Cleveland State University \\ w.kellogg@csuohio.edu
}

Brian Mikelbank

Levin College of Urban Affairs

Cleveland State University

b.mikelbank@csuohio.edu

\author{
Robert Laverne \\ Levin College of Urban Affairs \\ Cleveland State University \\ Manager of Education \& Training \\ Davey Tree Expert Company \\ RJ.Laverne@davey.com
}

Kathryn W. Hexter

Levin College of Urban Affairs

Cleveland State University

k.hexter@csuohio.edu

Résumé. Les nouveaux développements résidentiels annoncent le plus souvent une condamnation à mort pour les arbres qui se dressent sur leur chemin. Cette conséquence pourrait éventuellement être atténuée si les promoteurs prenaient conscience de l'avantage économique à être plus sélectif. La relation entre la préservation des arbres et le développement domiciliaire a malheureusement été peu étudiée. Le but de cette étude était de caractériser la valeur économique générée par la préservation d'arbres matures dans le cadre du processus d'aménagement du territoire à des fins résidentielles. L'étude a porté sur six comtés constituant la majeure partie de la ville de Cleveland en Ohio, États-Unis, et son marché de l'immobilier et du développement foncier. Une approche mixte quantitative et qualitative a été utilisée. Des données basées sur les SIG (système d'information géographique) et une série de modèles attrayants ont permis de déterminer la valeur du couvert forestier associée aux prix de vente de nouvelles maisons entre 2009 et 2011. Des entrevues qualitatives, avec des professionnels du développement foncier et de l'immobilier, ont révélé une corrélation nuancée de la valeur et des défis quant à la préservation des arbres durant le processus de développement domiciliaire des terrains résidentiels. Les méthodes antérieures d'estimation de la valeur économique des arbres ont été améliorées via la localisation aérienne des arbres sur les lots en utilisant Google Earth ${ }^{\mathrm{Tw}}$ et les données du National Agricultural Imagery Program (NAIP) (Programme national d'imagerie agricole) et par le recours à une approche de méthodes mixtes. L'étude a fourni des informations à une agence gouvernementale responsable de gérer le programme incitatif de développement intelligent de l'état.

Zusammenfassung. Neue Siedlungsentwicklungen sind meistens ein Todesurteil für die Bäume, die dem im Weg stehen. Dieses Verhalten kann verändert werden, wenn die Entwickler daran dächten, dass da ein ökonomischer Nutzen entstünde, wenn sie mehr selektiv entscheiden. Unglücklicherweise ist die Beziehung zwischen der Baumerhaltung und neuen Entwicklungen nicht gut studiert. Die Absicht dieser Studie liegt in der Charakterisierung des gewonnenen ökonomischen Wertes aus der Erhaltung von ausgewachsenen Bäumen während des Prozesses der Siedlungsentwicklung. Die Studie fokussiert auf sechs Landkreisen, die im Umkreis von Cleveland, Ohio, U.S. den Gewerbegebiets- und Landentwicklungsmarkt ausmachen. Es wurde ein gemischter, quantitativer und qualitativer Ansatz verwendet. GIS-basierte Daten und eine Serie von hedonistischen Modellen bestimmten den Wert von Baumkronenbedeckung in Verbindung mit neuen Hausverkaufspreisen in den Jahren 2009-2011. Qualitative Interviews mit beruflichen Entwicklern und Planern enthüllten eine nuancierte Verbindung zwischen Werten und Herausforderungen bei der Baumerhaltung während des Landentwicklungsprozesses. Vorherige Methoden zur Bestimmung des ökonomischen Wertes von Bäumen wurden nach vorne gebracht durch eine Luftbestimmung von Bäumen auf den Parzellen unter Verwendung von Google Earth ${ }^{\text {Tw }}$ und Daten aus dem National Agricultural Imagery Program (NAIP), sowie durch den gemischten, quantitativen und qualitativen Ansatz. Die Studie liefert Informationen an eine auf Bundesebene operierende Agentur, die die staatlichen, auf Anreizen basierenden Wachstumsprogramme verwaltet.

Resumen. El nuevo desarrollo residencial es a menudo una sentencia de muerte para los árboles que se interponen en su camino. Este comportamiento podría ser alterado si los desarrolladores pensaran que habría un valor económico siendo más selectivos. Desafortunadamente, la relación entre la preservación de los árboles y el nuevo desarrollo no está bien estudiada. El propósito de este estudio fue caracterizar el valor económico obtenido de la conservación de árboles maduros durante el proceso de desarrollo urbano. El estudio se centró en seis condados que constituyen el gran Cleveland, Ohio, EE.UU., bienes raíces y el desarrollo del mercado. Se utilizó un enfoque cuantitativo y cualitativo mixto. Los datos basados en SIG y una serie de modelos hedónicos determinaron el valor de la copa de los árboles asociados con los nuevos precios de venta de viviendas entre 2009 y 2011. Entrevistas cualitativas de desarrolladores y profesionales inmobiliarios revelaron una asociación matizada de valor y desafíos a la preservación de árboles durante el proceso de desarrollo. Los métodos anteriores para estimar el valor económico de los árboles se actualizaron a través de la ubicación aérea de los árboles en las parcelas utilizando Google Earth ${ }^{\mathrm{mx}} \mathrm{y}$ los datos del National Agricultural Imagery Program (NAIP) y mediante la aproximación del método mixto. El estudio proporcionó información a la agencia estatal que administra el programa de desarrollo basado en incentivos del estado. 